\title{
Reproductive Performance on the Maltese Islands during the First World War
}

\author{
Dr C Savona-Ventura \\ $M D, M R C O G$ \\ Department of Obstetrics \& Gynaecology, St. Luke's Hospital, MALTA
}

\section{Introduction}

The advent of war in any country heralds a total upheaval in the social and demographic characteristics of the community through "war casualties" and changes in the reproductive patterns in the population. Demographic changes may also be evident in neighbouring countries which may only be indirectly involved in the conflict. These indirect effects may have been more pronounced in the past, when the colonial policy practiced by various powers involved countries far-removed from the area of conflict. The present study aims to assess the effects of the First World War on a closed island community in the Central Mediterranean.

The immediate cause of the First World War was the spread of nationalism in the Balkans, as shown by the assassination of Archduke Francis Ferdinand and his wife at Sarajevo in June 1914. There were however various reasons as to why this conflict escalated to world-wide proportions. Among them was the prior division of Europe into rival camps by a system of alliances, originally defensive in character but made dangerous through a lessening of international trust by successive crises - Morocco in 1905, Bosnia in 1908-9 and Agadir in 1911. Anglo-German relations had worsened because of naval rivalry and trade competition. Austria-Hungary declared war on Serbia on 28 July 1914. Germany declared war on Russia and France and invaded Belgium in the first week of August. Britain declared war on Germany on the 4 August. Germany and Austria-Hungary were joined by Turkey (November 1914) and Bulgaria (October 1915), while the original Allies were supported by eighteen other states, the most important being Japan (August 1914), Italy (May 1915) and the U.S.A. (April 1917). The German Armistice was signed on 11 November 1918. The Maltese Islands formed part of the British Empire and thus became involved in the conflict (1).

During the First World War, the Central Mediterranean played a minor role since the major powers interested in the region - England, France, and Italy - were fighting on the same side. The Maltese Islands served as a "nurse of the Mediterranean" caring for wounded soldiers, as a dockyard for the British Navy, as a place of internment for prisoners-of-war, and as a home for refugees from Egypt and other neighbouring countries. One year after commencement of hostilities Malta had been declared a base hospital and by the Gallipoli evacuation in January 1916 , the Island could cater for 20,000 convalescents in 27 hospitals and convalescent centres throughout the
Island. By mid-1916, twelve months after the first convoy of $600 \mathrm{had}$ arrived, Malta had treated 80,000 convalescents. The War had a major economic impact on the Islands. The disruption of trade reduced government revenue, food prices tended to rise in response to shortages and higher freight rates, with the result that the cost of living soon rose rapidly. The prices of bread, sugar and meat were mostly affected in spite of the Government's strict control of prices and a subsidy to millers. Black market was rampant. This economic depression, coupled with the departing men who joined the Services, may have been contributory to the minor changes in demography that can be noted for the period $(2,3,4)$.

\section{Population changes}

The Maltese Islands are a group of small islands in the central Mediterranean, two of which are inhabited. The largest are Malta, which is 94.87 square miles in area and Gozo, which is 26.97 square miles. In the pre-war 1911 census, the Islands had a total civilian population of 105,601 males and 105,963 females, excluding nonMaltese servicemen and their families. A post-war census in 1921 showed total civilian population of 212,258 individuals with a male:female ratio of 0.94 . The population change in the two Islands during the period (Fig 1) shows very little change in the estimated population number of both Islands, any differences noted could be attributed to the normal gradual rise in total population and to correction in population numbers resulting from pre- and post-war census. The intracensal period 1911-1921 however showed only a $0.3 \%$ rise in population, a figure which is very much lower than the $14.5 \%$ rise noted in the previous intercensal period 19011911. This low rise suggests that a significant deceleration in population growth was brought on by the social circumstances resulting from the war $(5,6)$.

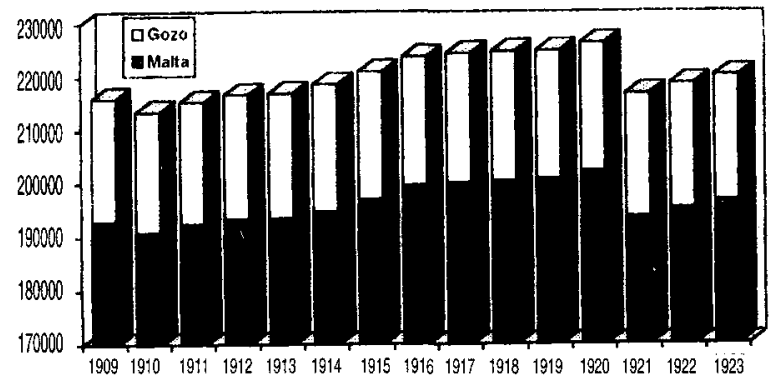

Fig 1. Maltese Population 1909 - 1923. 
The birth rate showed a fall from a mean of 34.8 per 1000 population in the preceding years 1909-1913 to 30.45 during the war years, reaching its lowest level of 29.81 per 1000 population in 1917. There was subsequently a steady rise with a slight post-war boom reaching a maximum of 36.41 per 1000 population in 1922. The overall mean for the following post-war years 1919-1923 stood at 34.25 per 1000 population. The differences were more marked in Gozo where the lowest birth rate reached was 22.75 per 1000 population in 1917 (Fig 2)(6).

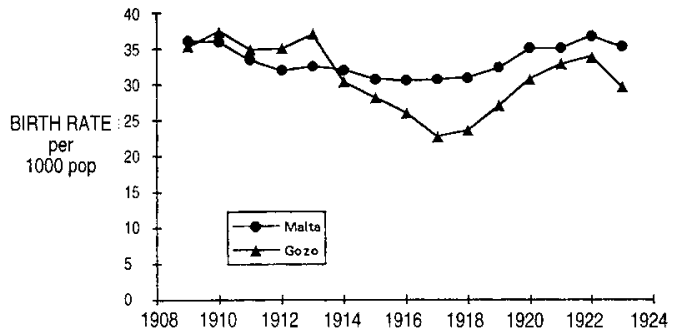

Fig 2. Birth rates: Maltese Islands 1909-1923.

The diminution in the birth rate during the war is not surprising in view of the disturbance to family life brought on by the calling up of a large number of men to the services. About $20 \%$ of the total male population contributed to the war effort. A number of Maltese joined the voluntary corps of the British Empire on missions to various destinations, such as Salonica and Gallipoli. The Maltese Labour Corps provided Maltese stevedoring labour for unloading ships and for construction work at Suvla Bay and Gallipoli. Several individuals from the Royal Malta Artillery and the King's Own Malta Regiment of Militia volunteered for services overseas and there were also large numbers serving in the Royal Navy and the Royal Navy Reserve. The first Maltese Corps were sent to the Dardanelles in September 1915, though individual men had joined the services earlier $(3,7,8)$.

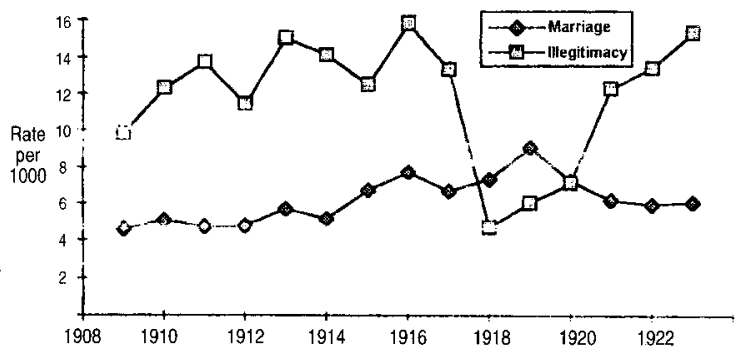

Fig 3. Marriage Rates per 1000 population Illegitimacy Rates per 1000 births: Maltese Islands 1909-1923.

The disruption in family life resulting from the departure of local male volunteers and the presence of a large number of foreign soldiers in the Islands did not appear to affect the illegitimacy rates during the wa्w years. There did not appear to be any significant rise during the war period suggesting that there was not $\frac{8}{8}$ lowering of the moral standards of the strongly Romam Catholic population. The marriage rates showed a increase during the war period possibly reflecting hasto marriages prior to joining the fighting forces. From the last year of the war until 1920 there was a marked drop is illegitimacy rates which returned to pre-war levels afte 1921 (Fig 3) $(6,9,10)$.

\section{Mortality rates}

The crude death rates in the Maltese Islands showed only a minimal rise during the war period 1914-1918 to reach a maximum of 26.39 per 1000 population in 1918 The figures for Gozo showed a similar pattern, though thes rates were generally lower and more fluctuant because 9 . the smaller population there (Fig 4).

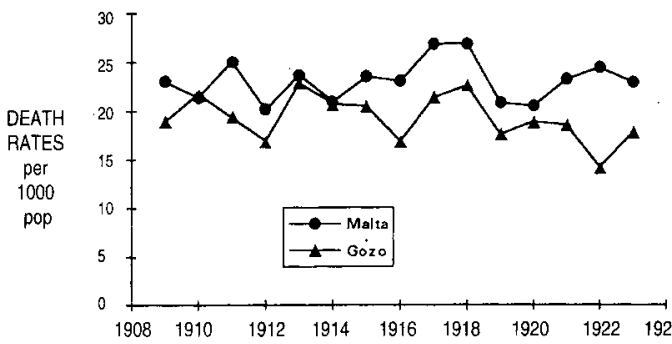

Fig 4. Crude Death Rates: Maltese Islands 1909-1923

The stillbirth+late abortion (Fig 5) rate showed a during the war years from a mean of 36.61 per 1000 tot 8 \% births in 1909-1913 (no data for 1910) to 40.25 in 1914 1918 (no data for 1914), reaching a peak rate of 55.39 i 1917. The rate subsequently reached a plateau ang declined slightly in the post-war period averaging $46.4 \hat{\theta}$ per 1000 total births in 1919-1923. This gradual increaso may reflect a deterioration in the socio-economis circumstances of the population brought on by the economic upheaval during the war years and after (6).

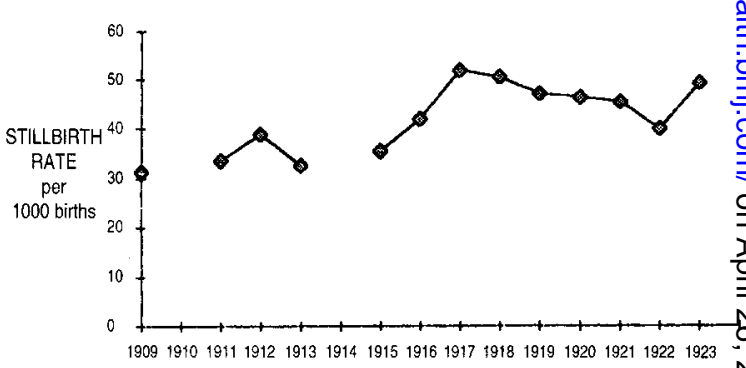

Fig 5. Stillbirth+late abortion rates: Maltese Island 1909-1923. 
The infant mortality rate showed a similar rise during the war years from a pre-war average of 311.7 per 1000 live births to 334.9 during the war period (Fig 6). The rate returned to levels lower than pre-war levels (245.1 per 1000 live births in 1919-1923) after the end of the war. The reason for the rise in the infant mortality rate during the war years did not appear to be related to the usual causes which in fact actually decreased in most instances. The rise appeared to be due to other general causes of infant deaths (Table 1). The post-war period saw a significant improvement in most of the important causes of deaths of early childhood. Deaths from diarrhoea maintained the high rates recorded in previous periods (6).

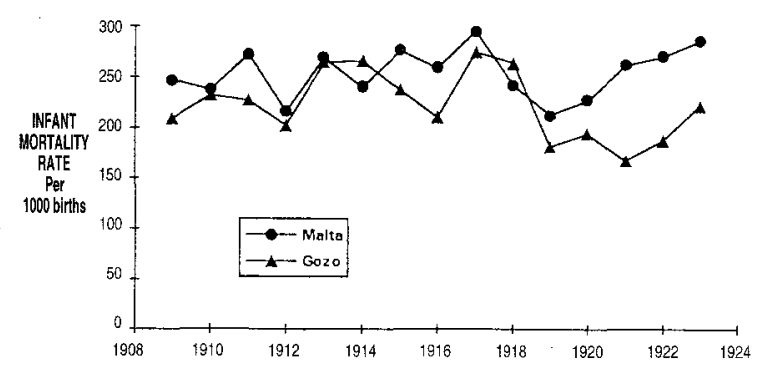

Fig 6. Infant Mortality Rates: Maltese Islands 1909-1923.

Table 1

Specific Infant Mortality Rates five-year averages per 1000 births

\begin{tabular}{lrrr}
\hline $\begin{array}{l}\text { Infant Deaths } \\
\text { Causes }\end{array}$ & $\mathbf{1 9 0 9 - 1 3}$ & $\mathbf{1 9 1 4 - 1 8}$ & $\mathbf{1 9 1 9 - 2 3}$ \\
\hline Diarrhoea & 139.6 & 133.5 & 133.3 \\
Debility & 96.2 & 92.1 & 62.7 \\
Atelectasis & 14.4 & 18.4 & 7.9 \\
Birth Injury & 6.5 & 3.1 & 7.7 \\
Prematurity & 5.8 & 2.8 & 4.8 \\
Other early & 0.5 & 0.5 & 0.5 \\
Infancy causes & & & \\
Malformation & 2.6 & 2.3 & 3.3 \\
Other causes & 46.2 & 82.2 & 24.8 \\
\hline
\end{tabular}

The maternal mortality rate showed a steady rise from the pre-war levels of 20.09 per 10,000 total births to 23,95 during the 1914-1918 war years and 28.99 in the subsequent five years (Fig 7). The progressive rise in maternal mortality appeared to be the result of a significant rise in deaths from the puerperal infection and hypertensive disease. The incidence of puerperal infection showed a similar progressive rise. The case fatality rates from sepsis appeared approximately stable in the first two periods decreasing in the post-war period. The case fatality rates were $41.7 \%$ in $1909-13,43.5 \%$ in $1914-18$ and $31.3 \%$ in $1919-23$. Deaths from the complications of hypertensive disease of pregnancy showed a significant rise during the war years, a rise that persisted in the post- war period. Deaths from haemorrhage rose during the war years, but subsequently fell in the post-war period. Deaths from other causes (including accidents of childbirth and the puerperium, and embolism/sudden death) showed a variable pattern (Table 2) (6).

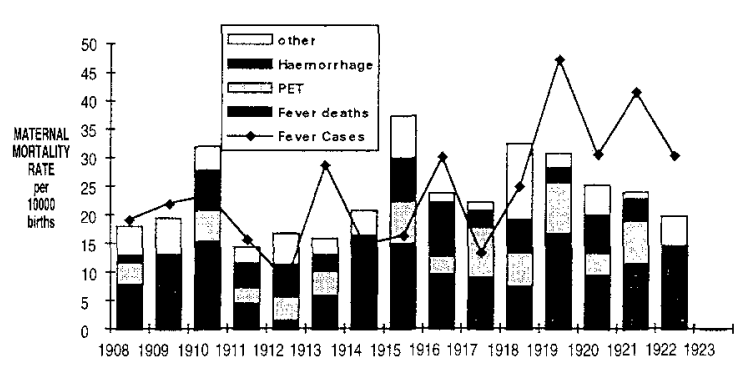

Fig 7. Maternal Mortality Rate: Maltese Islands 1909-1923.

Table 2

Specific Maternal Mortality Rates five-year averages per 10000 births

\begin{tabular}{lrrr}
\hline $\begin{array}{l}\text { Maternal Death } \\
\text { Causes }\end{array}$ & $\mathbf{1 9 0 9 - 1 3}$ & $\mathbf{1 9 1 4 - 1 8}$ & $\mathbf{1 9 1 9 - 2 3}$ \\
\hline $\begin{array}{l}\text { Puerperal fever: Cases } \\
\text { Puerperal fever: Deaths }\end{array}$ & 17.81 & 20.66 & 37.94 \\
Hypertension: Deaths & 3.29 & 8.99 & 11.77 \\
Haemorrhage: Deaths & 4.66 & 6.76 & 7.46 \\
Other causes: Deaths & 4.85 & 3.57 & 4.07 \\
\hline
\end{tabular}

\section{Discussion}

The Maltese population was not directly involved in the First World War. However the social and economic upheaval brought on by that war effected the demography of the population through the influence of reproductive performance with a decrease in birth rates and a slight increase in obstetric mortality rates. These changes confirm the strong relationship that exists between reproductive performance and the social circumstances of a population. Repeated population studies have shown that there is a social gradient in both perinatal and maternal mortality, so that the number of these deaths is high in the underprivileged classes, though the relationship is often fortuitous $(11,12,13)$.

The early years of the twentieth century saw a number of problems gradually increasing the misery of the lower social classes in Malta. Illiteracy was rife and housing was primitive especially in the Harbour areas. The high pre-war unemployment, offset by the needs of the Dockyard and Services during the war, shot up again in the post-war period. The cost of living increased rapidly as a result of the War economy in spite of the fact that there was never any serious food shortage in Malta. Bread soared from its pre-war price of $21 / 2 \mathrm{~d}$ per rotolo to $63 / 4 \mathrm{~d}$, 
sugar from $3 \mathrm{~d}$ to $1 \mathrm{~s} 2 \mathrm{~d}$, meat from $1 \mathrm{~s}$ to $3 \mathrm{~s} 6 \mathrm{p}$. Everything else was affected except rent. The Government exercised strict control on prices, organised distribution through its various boards and committees, allowed the sale of horseflesh and eventually subsidised the millers to the extent of $£ 2000$ per week to reduce the price of bread, All these factors contributed towards the deterioration in the social circumstances of the population, circumstances which partially contributed to the 7th June Riots by the Maltese in 1919. The post-war period saw the initiation by voluntary effort, assisted financially in part by the Civil Government, of measures for promoting maternal and infant welfare. A society - Mothers and Infants Health Association - was formed in February 1919. The defined objectives of this association were

1) the holding of periodical meetings of mothers at which advice and simple class teaching would be given on the hygiene of infancy, on the feeding and clothing of infants, on prevention of disease and infant sick nursing;

2) the establishing of home visiting of mothers and infants by voluntary lady visitors;

3 ) the establishing of baby clinics to carry out free consultations, at which babies would be examined at regular intervals;

4) the helping of needy mothers with gifts of baby clothing, with milk and other infant foods at cost price or free; and

5) the provision of cheap meals to mothers who could not get suitable and sufficient food at home. Three Consultation Clinics, at Hamrun, Valletta and Zejtun, were opened during 1919-20. These clinics offered supportive services to low economic status women in an attempt to lower the infant mortality rate. By 1926 the infant mortality rate was brought down to 260.8 per 1000 live births, while the stillbirth rate was 32.1 per 1000 total births. The maternal mortality rate was an estimated 38.7 per 10000 births $(3,6,14)$.

The infant mortality rates in the Maltese Islands rose slightly during the war years from 311.7 to 334.9 per 1000 births, returning to pre-war levels after the end of the war. The rate continued to fall further in the 1920-30s. However, the main decrease in infant mortality rate was noticeable after the Second World War. Most European countries experienced a gradual decrease in infant mortality rates in the first three decades of the twentieth century. Thus in the Netherlands the infant mortality rate fell from about 200 per 1000 births in 1900 to nearly 80 in 1920. This fall, which continued progressively in subsequent decades was, however, slightly offset by World War 1, when a slight peak reaching levels about 100 per 1000 births resulted. Similar patterns were also evident in other European countries. In the first half of the 1920's Norway had the lowest mortality rate, somewhat over 50 per 1000 live births, while in Sweden the rate was 60 . The rate averaged a little over 70 in the Netherlands and England and Wales. The rate in Belgium exceeded 100 per 1000 . The marked discrepancy between infant

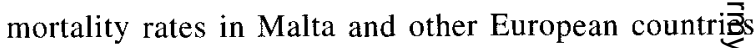
persisted well into the 1930 s $(15,16)$.

The maternal mortality rate in the Maltese Islands during the period rose from 20.09 to 28.99 per $100(9)$ births. It continued to rise progressively to reach 40.5 perr 10000 births in 1930-34. The rise was due to an increase in the cases of puerperal sepsis which accounted f $38.8 \%$ of deaths. Most European countries during this period saw a general tendency for maternal mortality $\stackrel{9}{0}$ remain on a plateau. It was not, of course, a complete level plateau, although it was close to one in England agd Wales. In Scotland the rates rose steadily from $1900 \oplus$ 1934. It also rose, but not until the late $1920 \mathrm{~s}$, on Scandinavia, the Netherlands, Belgium, and in cities \&f Paris and Amsterdam. The most notable feature of this plateau is the very wide difference in national levels of maternal mortality, a difference which was for the mest part maintained throughout this period. Thus during the period 1915-19, Belgium had a maternal mortality rate $\widehat{\text { q }}$ 79.8 per 1000 births, whereas Sweden and tre Netherlands had rates of 27.3 and 28.1 per 10000 births. England and Wales reported a mortality rate of 41.2. the above countries showed a variable rise from pre-war averages. About $40 \%$ of these deaths were due go puerperal sepsis (Sweden $46 \%$, Netherlands $3 \%$, Belgium $46 \%$, England and Wales $37 \%$ ). The situ再i was similar in the Maltese Islands where sepsis accolmit for $37.5 \%$ of maternal deaths $(13,17)$.

Another important cause of maternal deaths in the Maltese Islands was hypertensive disease of pregnoncy and its complications. This cause of death, which accounted for $19.9 \%$ of all maternal deaths, incres from the pre-war rate of 3.29 per 10000 births to a rate $\bar{g} f$ 4.76. The increase continued in the post-war perigd reaching 7.46 per 10000 births after which it declined $\Phi_{0}$ 4.38 in the pre-Second World War period. The increase continued in the post-war period. In other Europe ä countries, reports of incidence patterns of eclamp

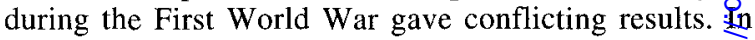
German hospitals the incidence of eclampsia was noted decrease from $1.44 \%$ in $1909-1913$, to $0.85 \%$ in 191 鹿1918 , returning to $1.7 \%$ in 1919-1923. Since the 1915 was preceded by a period of food shortage in Germapy which had been alleviated by 1919 , the decreased incidence in eclampsia has been attributed to wartine dietary restriction, particularly of fats and protein. In the Maltese Islands, unlike other European countries whege the social circumstances ameliorated with the end of the war, the dietary shortages resulting from the rise in cogt of living had persisted in the post-war period. The European data for war-time changes in eclampsia incidence during the First World War are scantid. Similarly the data obtained during the Second World W-ar from various European countries is also inadequate a no conclusions can be reached about the influence of wor. on the incidence of pre-eclampsia. The interpretation 87 the changes in incidence rates of hypertensive disease 
during time of war is difficult, since the reports do not account for the changing patterns of reproduction during wartime, including a fall in the birth rate and a fall in the number of primiparous births $(17,18,19)$.

The demographic changes resulting from war are very much more dramatic when the conflict directly involves the population. The extent of these changes was exhibited during the Second World War, when the Maltese Islands played a more active role in the conflict. Throughout that war there were a total of 2537 alerts of air attacks with 492 day and 574 night raids. The onset of hostilities on the Islands required a re-organisation of the maternity and child health services with an increased emphasis on hospital confinement, which because of the disruption in civilian life increased from the pre-war $4.3 \%$ level to $14.1 \%$ in 1941 . The birth rate decreased dramatically during the war years. The neonatal and infant mortality rate increased mainly as a result of a greater incidence of diarrhoeal disease and congenital debility. The stillbirth rate during the war years was overall lower than the prewar period possibly reflecting better antenatal and intrapartum supervision. The maternal mortality rate showed a decrease mainly as a result of a decrease in the incidence in puerperal sepsis and deaths from haemorrhage. The Maltese reproductive performance appears to show some similarities to performances recorded by occupied countries, the differences being attributable to the organisation of the health service (18).

The contribution given by the Maltese civil population during the Second World War was recognised by the awarding of the George Cross by King George VI on 15 April 1942. The recognition of the contribution of the Islands to the war effort during the First World War was less formal. However the Maltese contribution to the war was acknowledged. When Lord Paul Sanford Methuen Governor of Malta sent his congratulations to King George V on the Armistice in 1918, the King replied: ".... Let me assure you that I am fully conscious of the important and patriotic part that Malta has played during these years of warfare ...."(7). Deaths from medical causes during war must be considered "sick war casualties" since the adverse health and social conditions brought on by warfare contribute to these deaths.

\section{REFERENCES}

1. PALMER AW. A dictionary of Modern History 17891945. England: Penguin Books, 1974; 353-355.

2. Blouet B . The story of Malta. Malta: Progress Press, 1989: 180.
3. LAFERLA AV . British Malta. Vol. II (1872-1921). Aquilina, Malta: 1947: 193-218.

4. MACKINNON A. The nurse of the Mediterranean. London: Hodder \& Stoughton, 1916: 9,42.

5. Census '85: Vol 1 - A Demographic Profile of Malta $\bigcirc$ and Gozo. Malta: Central Office Statistics, 1986: 43 . क्

6. Report on the Health of the Maltese Islands: 1909-10: to 1923. Malta: Government Printing Office, annual $\stackrel{\vec{\rho}}{\rightarrow}$ publication, 1910-1926.

7. Abela AE. Governors of Malta - 6: The First World War and after. The Sunday Times (of Malta), 11 November $1990 ; 30$.

8. Laspina S. Outlines of Maltese History. Malta: in Aquilina, 1970, 267.

9. Reports of the workings of Government Departments during the financial years 1909-10 to 1923-24. Malta: Government Printing Office, Section H-Police, 19101926.

10. Savona-Ventura C. Illegitimacy in the Roman Catholic Community of Malta. Planned Parenthood in Europe 1993; 22(2):30-32.

11. BAIRD D. Social class and foetal mortality. Lancet 1947; ii:531.

12. Turnbull aC, Tindall VR, Robson G, Dawson MP, ClOAKE EP, Ashley JSA. Report on Confidentiag enquiries into Maternal Deaths in England and Wale्षृ 1979-1981. London: HMSO, 1986: 10.

13. Loudon I, Maternal Mortality: 1880-1950. Somm Regional and International Comparisons. Soci $\vec{\oplus}$ History of Medicine, 1988; 1(2): 183-228.

14. Annual Report on the Health of the Maltese Islane during 1926. Malta: Government Printing Office 1927.

15. Vassallo-Agius P. An Outline of the Development of Paediatrics in Malta in the Twentieth Century Paediatric Update, (P Vassallo Agius, R Parascandolo, C Vella. eds.). Malta: University Press, 1991: 110126.

16. Stewart WH, Cohen WJ. Infant loss in the Netherlands. Washington: National Center for Health Statistics, 1968: 9-10.

17. Savona-Ventura C, Grech ES. Maternal Mortality in the Maltese Islands. Int J Gynaecol Obstet 1987; 25:283-290.

18. Savona-VEntura C. Reproductive performance on the Maltese Islands during the Second World War. Med Hist 1990; 34:164-177.

19. MacGillvray. Pre-eclampsia. The hypertensive 8 disease of prenancy. London: WB Saunders, 1983: 34-35. 